\title{
FULL DEPOSIT INSURANCE AND THE MORAL HAZARD PROBLEM: THE CASE OF THE TURKISH BANKING SYSTEM*
}

\author{
ALÖVSAT MÜSLÜMOV**
}

Doğuş University

\begin{abstract}
This paper analyzes the effects of the full deposit insurance system introduced in 1994 on the financial performance of Turkish commercial banks using the experimental design approach. The research findings support the moral hazard hypothesis. The findings indicate that banks subject to moral hazard behavior show significant increases in foreign exchange position risk and deterioration in capital adequacy relative to their benchmark after the introduction of the full deposit insurance system. This excessive risk-taking is related to the moral hazard behavior by commercial banks. The research results indicate that the complete deposit insurance system distorts the incentive structure of commercial banks and thus prevents the proper functioning of the market discipline mechanism and leads to excessive risk-taking.
\end{abstract}

Key words: banking, deposit insurance, moral hazard.

\section{TAM GÜVENCELI MEVDUAT SIGGORTA SISTEMI VE AHLAKİ TEHLIKKE SORUNU: TÜRK BANKACILIK SISTEMİ ÖRNEĞI}

\begin{abstract}
ÖZET
Bu çalışmada deneysel tasarım yaklaşımı kullanılarak 1994 yılında uygulamaya konulan tam güvenceli mevduat sigorta sisteminin Türk ticari bankalarının finansal performansı üzerinde etkileri analiz edilmiştir. Araştırma bulguları ahlaki-tehlike savına destek sağlamaktadır. Bu bulgulara göre, tam mevduat sigorta sistemi uygulanmasının başlanmasından sonra ahlaki-tehlike sorununa duyarlı bankaların yabancı para pozisyonu riski anlamlı şekilde artmış, sermaye yeterliliği ise azalmıştır. Aşırı risk üstlenme davranışı ticari bankaların ahlaki-tehlike sorununa duyarlılı̆̆ Araştırma bulguları, tam güvenceli mevduat sigorta sisteminin ticari bankaların teşvik yapısını bozduğunu, piyasa disiplin mekanizmasının düzgün çalışmasını engellediğini ve bankaların aşırı risk üstlenmesine yol açtı̆̆ını göstermektedir.
\end{abstract}

Anahtar kelimeler: bankacıllk, mevduat sigorta sistemi, ahlaki tehlike,

* Earlier drafts of this study were presented at the 7th Spring Meeting of Young Economists, Leuven, April 2003 and the 6th METU Conference in Economics, September, 2002.

** Alövsat Müslümov is an Associate Professor in the Department of Economics-Finance at Doğuş University, 34722 , Acıbadem, Istanbul, Turkey. E-mail:amuslumov@dogus.edu.tr 
Bank runs occur when many or all of a bank's depositors attempt to withdraw their funds simultaneously. The failure of any single bank may result in a chain reaction (domino effect) and eventually, all remaining banks in the system may face a greater probability of failure (Paroush, 1988; Chari and Jagannathan, 1988). Therefore, the failure of any single bank to meet its obligations makes the whole banking system unstable and results in reduced public confidence in the system as a whole. Considering the huge fiscal costs due to the instability in the banking system, financial safety nets are erected to decrease the vulnerability of the banking system to the contagion effects of individual bank runs. One of the main elements of these safety nets is the deposit insurance system, which covers the losses of depositors in the event of the bankruptcy of a single bank.

However, the introduction of the deposit insurance system may result in a distorted incentive structure in the banking system, since it result in informational asymmetries among contracting parties. Contracting parties consist of bank, depositors, and supervisors in the environment in which the deposit insurance system does not exist. In this case, depositors who benefit from the returns also bear the risk of losing their deposits in the event of the bank's bankruptcy. Therefore, they exert a market discipline mechanism over the bank by shifting their funds or adjusting their expected rates of return on the basis of the bank's riskiness (Park, 1995; Park and Persistani, 1998; Demirgüç-Kunt and Huizinga, 2000; Baer and Brewer, 1986; Hannan and Hanweck, 1988; Ellis and Flannery, 1992). Consequently, the bank's default risk becomes upper-bounded by the constraints of the market discipline mechanism.

With the introduction of the deposit insurance system, the number of contracting parties increases and consists of bank, depositors, supervisors, politicians, and taxpayers. To put it simply, under the deposit insurance system, politicians promise depositors that the taxpayers will pay the bill of their losses if a bank proves unable to meet its obligations. This type of deposit insurance design can be viewed as a multi-party principal-agent problem and generates a moral hazard behavior (Akerlof and Romer, 1993; Scott and Weingast, 1994; Kane, 1995; McKinnon and Pill, 1999; Kane and DemirgüçKunt, 2001). Moral hazard behavior implies that the distorted incentive structure in the banking system due to the deposit insurance will give an incentive to the banks to go broke for profit at the taxpayers' expense. The depositors no longer have any reason to be concerned with the financial condition of the bank and therefore, they do not constitute a source of threat for the bank. Consequently, deposit insurance removes the depositors' constraint over the bank and the bank may become involved in gambling at the taxpayers' expense (Akerlof and Romer, 1993).

This paper analyzes the impact of full deposit insurance on the financial performance of commercial banks in the Turkish banking system using the experimental-design approach. For this purpose, the financial statements of Turkish private commercial banks are analyzed and industry-adjusted variable values are used to remove the effects of economy- and industry-wide factors on financial performance changes.

The paper is organized as follows. The next section describes deposit insurance arrangements in the Turkish banking system. Later, sample and data used in the study are presented, and the research design is discussed. This is followed by a discussion of the research findings, and those of the sensitivity analysis. Finally, the conclusion section gives a brief summary and discusses the implications of the study 


\section{THE TURKISH BANKING SYSTEM AND FULL DEPOSIT INSURANCE}

The Turkish banking system has shown considerable growth since 1980. Total bank assets grew over 7.2 times in the 1980-1999 period, whereas GNP has grew only 2.7 times. ${ }^{(1)}$ The banking system has gained dynamic structure and played an important role in the development of the Turkish economy. However, long-standing economic imbalances, especially chronically high inflation, huge public sector borrowing requirements and the use of generous tax credits and exemptions to enhance the attractiveness of public sector securities over private sector borrowing, have constrained the growth of the banking system severely. These structural imbalances combined with the full deposit insurance system have distorted the incentive structure of the Turkish banking system.

The first arrangements for the deposit insurance system in Turkey were introduced in the 1930s. Today the Saving Deposit Insurance Fund (SDIF), established in 1983, constitutes the basis of the existing deposit insurance system. The deposit insurance scheme introduced in 1983 provided a legally enforceable guarantee on deposits with coverage of 3,000,000 TL (13,405 USD) per person on all principal. Since inflation eroded deposit insurance coverage, periodic adjustments were made on the coverage amount. The deposit insurance coverage was raised to $6,000,000 \mathrm{TL}$ (8,961 USD) in $1986,75,000,000$ TL (10,910 USD) in 1992, and 150,000,000 TL (13,592 USD) at the beginning of 1994.

The introduction of full deposit insurance followed an economic crisis in 1994. During the 1990s, Turkish banks became heavily engaged in investing TL nominated short-term government papers that offered abnormally high real interest rates. These investments were financed primarily by deposit growth and foreign borrowing. This strategy worked well during the 1989-93 period (and later in the 1995-2000 period), when the returns of TL nominated assets were abnormally higher than the nominal depreciation rate of the TL and inflation. In order to benefit from this profit opportunity, commercial banks increased their risk positions significantly. However, this strategy resulted in financial disaster when devaluation expectations started to escalate in late 1993 (and later in 20002001). Companies, banks and foreign investors with short positions in foreign currency attacked the exchange bureaus in panic at the beginning of 1994. Exchange rates increased from 12,500 TL/USD to $37,500 \mathrm{TL} / \mathrm{USD}$ within a few months. The sudden rise in exchange and interest rates damaged the health of the whole domestic economy and banking system.

Three domestic commercial banks (TYT Bank, Marmarabank and Impexbank), which held more than 1 trillion TL deposits of approximately 18,000 depositors, declared their bankruptcy on April 11, 1994. The loss was estimated as 3 trillion TL in this debacle. Viewing the weak financial position of other commercial banks within the system, the Turkish authorities greatly feared the contagion threat of these bankruptcies. The loss of confidence in the whole banking system might have resulted in the deposit-withdrawal reaction of mainly larger depositors who had substantial weight in the Turkish banking system. Full deposit insurance was viewed as a way to prevent deposit withdrawals and fullscaled bank runs eventually. This led to the introduction of the full deposit insurance system on April 24, 1994 by government decree.

However, full deposit insurance dramatically changed the risk attitude of the banking system. The introduction of full insurance coverage made it easier to raise deposits regardless of the bank's 
riskiness. Low-quality banks became engaged in practices of charging extra-high deposit rates and lending to over-risky projects in the hope of growing out of their liquidity and solvency problems (World Bank, 2000). This excessive risk-taking increased the default risk of the whole banking system. In order to maintain confidence and prevent systemic risk in the banking system, from 1997 to July 2002, the ownership of 20 banks was transferred to the SDIF. The direct fiscal burden of these transfers on the economy has exceeded 20 billion USD. ${ }^{(2)}$ Moreover, the banking crisis caused the loss of confidence in the domestic financial markets and the economy faced the devastating effects of the economic crisis in 2000-2001. Recognizing the adverse effects of the full deposit insurance system on the performance of the banking system, a plan for the gradual reduction of the full deposit insurance was put into operation in June 2000.

\section{RESEARCH DESIGN}

\section{Research Model and Testable Predictions}

Previous studies published in the theoretical and empirical literature suggest that the deposit insurance system has adverse effects on the market discipline mechanism and leads to the moral hazard problem. The moral hazard problem leads to excessive risk-taking by commercial banks and the erosion of bank sources. In this section, the hypothesis is tested that the moral hazard problem results in

1) decrease in capital adequacy,

2) decrease in asset quality,

3) decrease in management efficiency,

4) increase in earnings,

5) increase in liquidity.

Table 1 presents testable predictions and empirical proxies for this study.

The empirical proxies of this study used to represent research variables are similar to those used in the CAMEL rating system of banks where CAMEL stands for capital adequacy, asset quality, management, earnings, and liquidity.

Capital adequacy is measured using two different empirical proxies. The standard capital ratio is the ratio of a bank's capital base to its risk-weighted assets, non-cash credits, and obligations. ${ }^{(3)}$ Riskweighted assets, non-cash credits, and obligations consist of a bank's assets, non-cash credits, and commitments grouped in categories based on their risk weightings in various percentages. Standard capital ratio measures whether the bank retains sufficient capital against losses which may results from existing and potential risks. However, since the standard capital ratio may suffer from the method of measuring risky assets, alternative capital are introduced to the assets ratio to partially compensate for the biases arising from using standard capital ratio alone. This variable does not discriminate assets in terms of risk, and therefore, is not affected by the method of measuring risky assets. It is predicted that the moral hazard behavior of banks vulnerable to the full deposit insurance system will decrease their capital adequacy. 
Table 1

Summary of Testable Predictions

\begin{tabular}{|c|c|c|}
\hline Variable & Proxies & $\begin{array}{c}\text { Predicted } \\
\text { Relationships }\end{array}$ \\
\hline \multirow[t]{3}{*}{ Capital Adequacy } & Standard Capital Ratio (SCR) = Capital / (Risk-weighted & \\
\hline & Assets, Non-Cash Credits and Obligations) & $\mathrm{SCR}_{\text {post }}<\mathrm{SCR}_{\text {pre }}$ \\
\hline & Capital / Total Assets (CAP) & $\mathrm{CAP}_{\text {post }}<\mathrm{CAP}_{\text {pre }}$ \\
\hline \multirow[t]{3}{*}{ Asset Quality } & Credit Risk = Nonperforming Loans $/$ Total Loans $(N C R)$ & $\mathrm{NCR}_{\text {post }}>\mathrm{NCR}_{\text {pre }}$ \\
\hline & Foreign Exchange Position Risk = Foreign Exchange & \\
\hline & Assets / Foreign Exchange Liabilities & $\mathrm{FXP}_{\text {post }}<\mathrm{FXP}_{\text {pre }}$ \\
\hline \multirow[t]{3}{*}{ Management Efficiency } & (Salaries and Employee Benefits + Reserve for Retirement) / & \\
\hline & Total Assets (SAL) & $\mathrm{SAL}_{\text {post }}>\mathrm{SAL}_{\text {pre }}$ \\
\hline & Operational Expenses / Total Assets (OPX) & $\mathrm{OPX}_{\text {post }}>\mathrm{OPX}$ pre \\
\hline Earnings & Net Income / Average Total Assets (INC) & $\mathrm{INC}_{\text {post }}>\mathrm{INC}_{\text {pre }}$ \\
\hline Liquidity & Liquid Assets / Total Assets (LIQ) & $\mathrm{LIQ}_{\text {post }}>\mathrm{LIQ}_{\mathrm{pre}}$ \\
\hline
\end{tabular}

Note: This table details the economic characteristics examined for changes after the introduction of the full deposit insurance system. The empirical proxies employed in the analyses are also presented and defined. The index symbols POST and PRE in the predicted relationship column stand for the post-full deposit insurance system and the pre-full deposit insurance system, respectively.

The asset quality is measured by two indicators. The ratio of nonperforming assets to total loans represents a bank's credit risk. It is predicted that a vulnerable bank's credit risk will increase after the introduction of full deposit insurance.

The second asset quality indicator is the foreign exchange risk, which is measured by the ratio of foreign exchange assets to foreign exchange liabilities. This variable should be interpreted carefully. The deviations of the ratio of foreign exchange assets to foreign exchange liabilities from one in either direction show increasing foreign exchange exposure. The investment atmosphere in the 1990s encouraged banks to borrow abroad with foreign currency and invest in short-term domestic government papers in local currency, thereby opening their foreign exchange positions. Though this investment strategy yielded high returns in the short term, it turned into a disaster when the local currency was devalued. The moral hazard behavior of banks is predicted to increase the foreignexchange risk of Turkish banks. 
Two indicators are used to measure banks' management efficiency. The first indicator is calculated by dividing salaries and employee benefits, and reserve for retirement to total assets. Due to some shortcomings of this ratio (i.e. highly efficient and profitable banks are inclined to pay more wages to their employees and managers), a complementary operational expenses-to-total assets ratio is also used

Bank profitability is measured by a return on assets ratio. The increased risk-taking behavior of vulnerable commercial banks is predicted to increase banks' profitability.

The liquid assets-to-total assets ratio is used as a proxy of banks' liquidity and interest rate risk. Banks exposed to moral hazard behavior are expected to increase their investment in short-term domestic government papers, which was the most attractive investment option in the 1990s in Turkey. Therefore, increases in the liquid assets of banks may cause huge losses when the financing costs of these investments exceed their rates of returns. The trend analysis of the research variables is provided in Figure 1.

\section{Sample and Data}

The research model is focused on the impact of full deposit insurance on the financial performance of banks operating in the Turkish banking system. However, not all of the banks in the Turkish banking system are vulnerable in the same degree to moral hazard behavior due to the full deposit insurance system. Therefore, the sample space of all banks is divided into research and control sample categories according to their vulnerability to full deposit insurance. The full deposit insurance system covers the domestic deposits of all commercial banks operating in Turkey. Since state commercial banks are always under the shield of full deposit insurance due to their nature, the introduction of full deposit insurance is not expected to affect their financial performances significantly. Moreover, since the full deposit insurance system is related to commercial banks, development and investment banks also are not expected to show moral hazard behavior. Consequently, it is domestic and foreign-owned private commercial banks that are vulnerable to moral hazard behavior. Considering this vulnerability, the research sample is made up of all domestic and foreign-owned commercial banks, whereas the control sample includes state commercial banks and development and investment banks. Table 2 details the specification of the sample space of banks operating in the Turkish banking system. The source of the data used in this study is the Banking Association of Turkey.

\section{Research Design}

The measurement of the role of moral hazard behavior on the financial performance changes of banks is a complex task, since it is obviously impossible to trace all of the financial performance changes after the introduction of the full deposit insurance system to the moral hazard problem. Therefore, a two-staged experimental design approach is adopted and the post-1994 financial performance data of banks are compared with the pre-1994 benchmark using raw and industry-adjusted variable values. 1994 is taken as the turning point since full deposit insurance was introduced in that year. It could be argued that 1994 was not an optimal breaking point in the Turkish banking sector and a worsening trend in the risk of banking system could be attained if the breaking point were taken as 1990 . However, this argument does not necessarily imply that the introduction of the deposit insurance system did not constitute a breaking point in the performance changes of the banking sector in Turkey. 
Figure 1.

Trend Analyses of Research Variables

Standard Capital Ratio (\%)

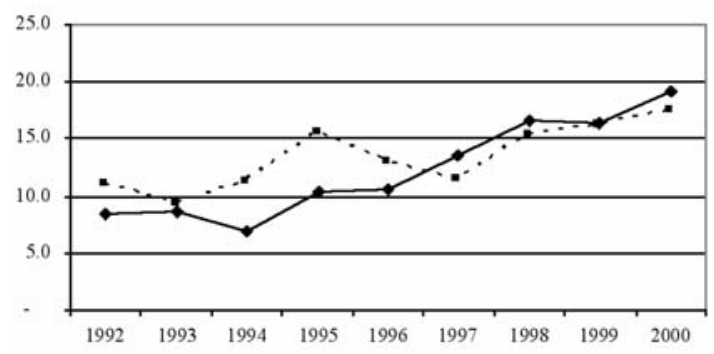

$\longrightarrow$ Control Sample $\cdots \cdot \cdots$ Research Sample

Credit Risk (\%)

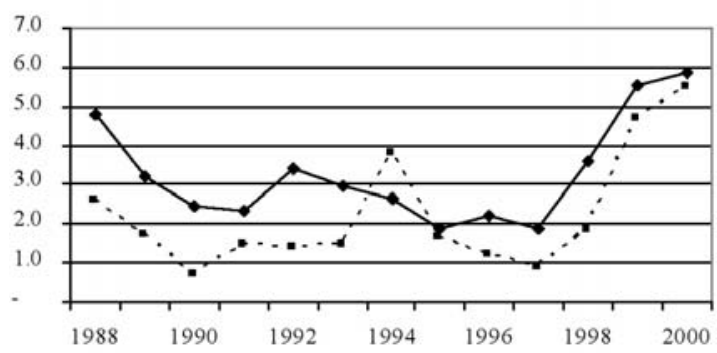

$\longrightarrow$ Control Sample...$\cdot$ Research Sample

Salaries / Total Assets (\%)

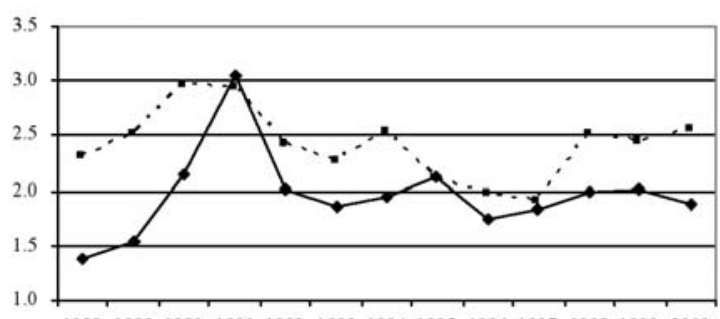

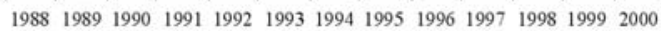

$$
\longrightarrow \text { Control Sample } \cdots \cdots \text { Research Sample }
$$

Profitability (\%)

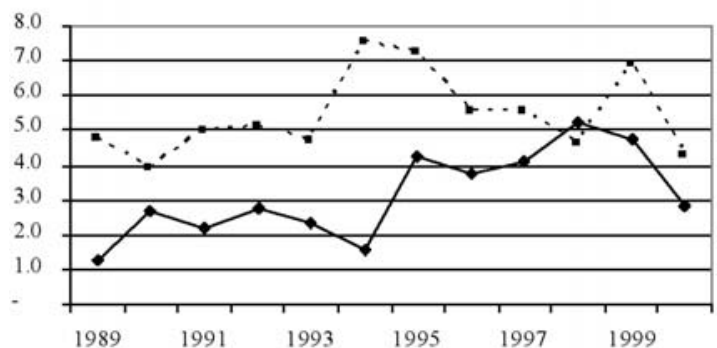

$$
\text { —C Control Sample ...... Research Sample }
$$

Capital-To-Total Assets Ratio (\%)

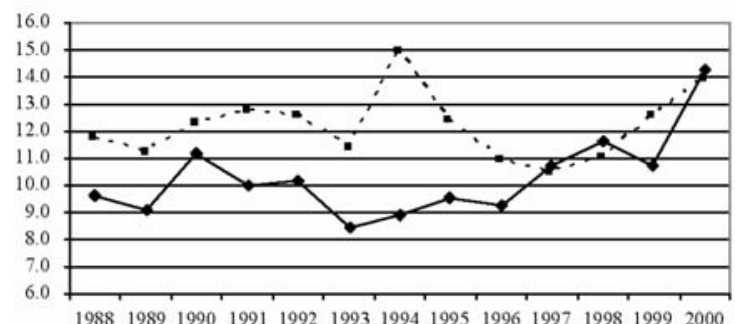

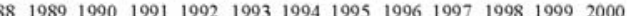

$\longrightarrow$ Control Sample $\cdots \cdots \cdot$ Research Sample

Foreign Exchange Position Risk (\%)

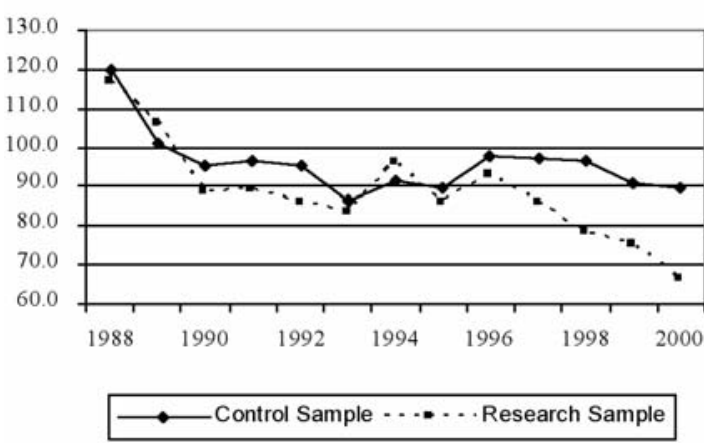

Operating Expenses / Total Assets (\%)
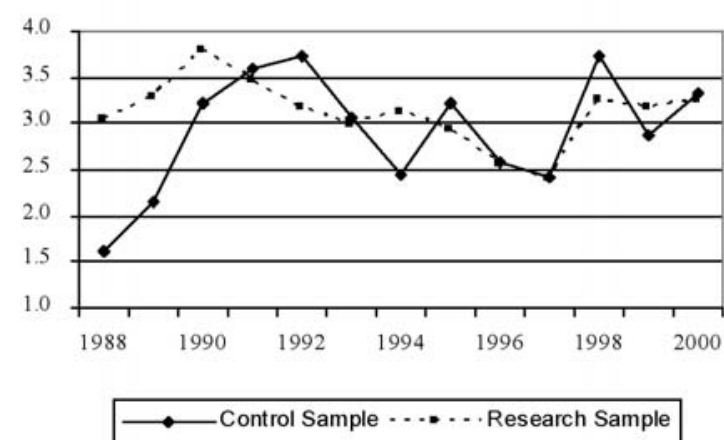

Liquidity (\%)

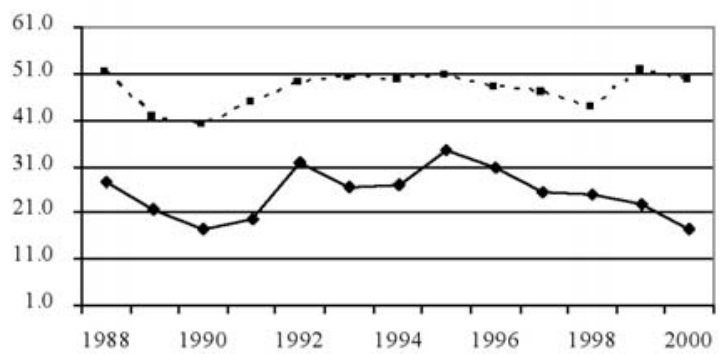

•-Control Sample...$\cdots$ Research Sample 
Table 2

Sample

Research Sample

Foreign-owned Private Commercial Banks

Domestic-owned Private Commercial Banks

Control Sample

State Banks

Development and Investment Banks

Source: Banking Association of Turkey (31.12.2000)

In the first stage, the post-1994 financial performance data of the research sample is compared with the pre-1994 benchmark to measure the change in performance. Some of the adverse changes in the financial performance of the post-1994 period can be attributed to the moral hazard behavior; however, economy- and industry-wide factors also have a great effect on these changes. Therefore, the financial performance changes in this analysis will reflect aggregate effects of the moral hazard behavior, economy- and industry-wide factors.

In order to eliminate the effects of economy- and industry-wide factors on the financial performance changes and to obtain the purified effects of moral hazard behavior on performance changes, the study proceeds to the second stage and use industry-adjusted performance measures of all domestic and foreign-owned private commercial banks. The industry-adjusted performance of all banks within the research sample is calculated by subtracting the median of the control group from the sample bank value for each year and bank. Industry-adjusted values will eliminate the effects of economy- and industry-wide factors on the financial performance changes and reflect the effects of moral hazard behavior on the banks' performance.

To test the research predictions, the empirical proxies for every bank for a 12-year period are compared: six years before (1988-1993) through six years after (1995-2000) the introduction of the full deposit insurance system. Then the median of each variable for each bank is calculated over the 1988-1993 and 1995-2000 windows. 1994 is excluded from the analysis since the variable values for that year bear the crossing effects of the existence and non-existence of the full deposit insurance system.

Having computed the pre- and post-1994 medians, the nonparametric Wilcoxon signed-rank test is used as the principal method of testing for significant changes in the variables. Since financial ratios do not follow normal distribution, the interpretation of the findings of parametric analysis becomes difficult. The small sample sizes also lead to the selection of nonparametric tests as a suitable method of testing financial performance changes.

The conclusions are based on the standardized test statistic Z, which for samples of at least 10 follows approximately a standard normal distribution. In addition to the Wilcoxon test a (binomial) proportion 
test is used to determine whether the proportion ( $\mathrm{p}$ ) of banks experiencing changes in a given direction is greater than would be expected by chance (typically testing whether $p=0.5$ ). The finding that an overwhelming proportion of banks changed performance in the same direction may be at least as informative as a finding concerning the median change in performance. Since the research hypotheses are unidirectional, single-tailed tests are used in this study.

\section{EMPIRICAL RESULTS}

In this section, the empirical results (in Table 3 and 4) for the raw and industry-adjusted values of the research sample are discussed. For each of these analysis stages, whether the banks experience significant changes in the variable values after the introduction of full deposit insurance will be examined.

\section{Capital Adequacy}

The research findings show that the raw values of the capital adequacy ratios exploited in this study do not show significant changes after the introduction of the full deposit insurance system (Table 3 ). However, the industry-adjusted values of the standard capital ratio of the banks subject to the moral hazard problem decreased on average (median) five percentage points (one percent) after the introduction of the full deposit insurance system and $72 \%$ of all banks experienced a decreasing standard capital ratio (Table 4). The Wilcoxon and proportion test statistics are significant at a one percent level. The industry-adjusted values of capital-to-total assets ratio do not show any significant changes after the introduction of the full deposit insurance system.

Therefore, it can be concluded that banks subject to the moral hazard problem experience partially deteriorating capital adequacy relative to their benchmark after the introduction of full deposit insurance. However, this finding is not robust, since a similar pattern is not observed for the alternative capital adequacy ratio. This weak evidence may be due to the banking regulations, since banks in Turkey have been required to maintain an eight percent minimum capital adequacy ratio and report their capital adequacy position quarterly since the 1994 banking crisis. This restriction may have prevented further declines in their capital adequacy.

\section{Asset Quality}

The asset quality of commercial banks was measured by two indicators in this study: credit risk and foreign exchange risk. The raw and industry-adjusted values of non-performing loans/total loans ratio (NCR), which is the indicator of credit risk, shows no significant changes after the introduction of the full deposit insurance system (Table 3 and 4). The Wilcoxon and proportion test statistics are not significant at conventional levels.

McKinnon and Pill (1999) show that the deposit insurance system provides incentives to banks to increase their foreign borrowing and incur foreign exchange risk. Consistent with this hypothesis, it is found that banks subject to moral hazard behavior open their foreign exchange positions significantly. The foreign exchange position risk is measured by foreign exchange assets-to-foreign exchange liabilities ratio (FXP) in this study. As mentioned in the previous section, a deviation in the FXP value from 1 in either direction means an increasing foreign exchange exposure. The raw values of the FXP of the research sample decrease on average (median) 15 percentage points (seven percent) 


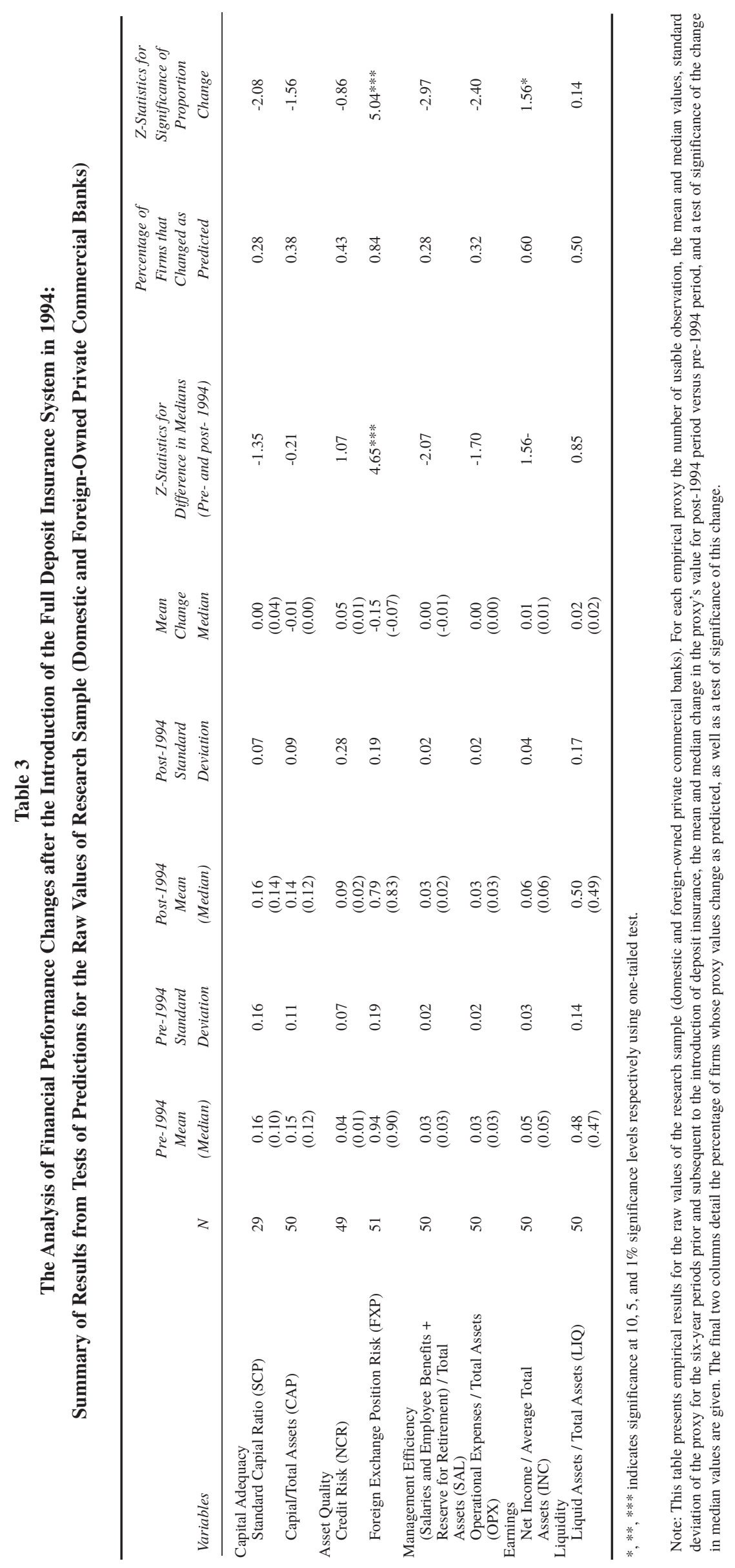




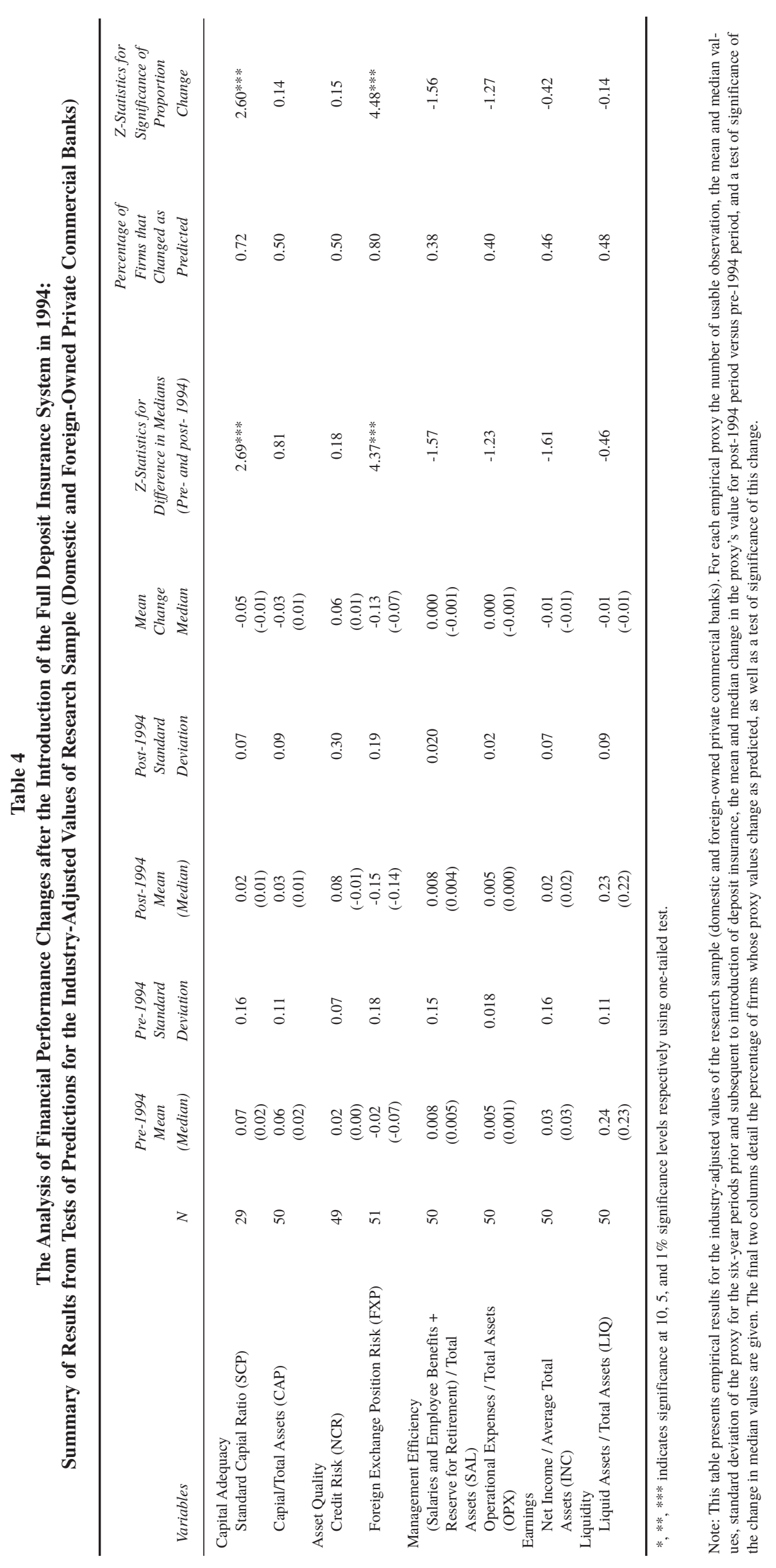


and $84 \%$ of all domestic and foreign-owned private commercial banks experience decreasing FXP ratios after the introduction of the full deposit insurance system (Table 3). The Wilcoxon and proportion test statistics are significant at a one percent level. Moreover, the industry-adjusted value of FXP on average (median) decreases 13 percentage points (seven percent) and 80\% of all domestic private commercial banks experience decreasing industry-adjusted FXP ratios after introduction of the full deposit insurance system (Table 4). The Wilcoxon and proportion test statistics are significant at the one percent level again.

These results show that the increasing foreign exchange risks of banks can be attributed to the introduction of the full deposit insurance system, since the changes in the foreign exchange position remains significant even after controlling for economy- and industry-wide effects. Banks facing less pressure from depositors with the introduction of the full deposit insurance system are willing to incur large open foreign-exchange positions. Considering the appeal of high interest rate premiums on government debt securities in recent periods, banks have become heavily engaged in overinvestment in government papers and opening their foreign-exchange positions. However, this strategy was one of the reasons behind the financial crisis in 2000-2001, when domestic currency depreciation far exceeded interest rate premiums.

\section{Management Efficiency}

Moral hazard behavior is predicted to increase the operating costs of commercial banks. Agency cost is measured by two variables in this study. The first variable is the (salaries and employee benefits + reserve for retirement)/total assets (SAL) ratio, and the second variable is the ratio of operational expenses to total assets (OPX).

The raw and industry-adjusted agency cost variable values to the banks subject to the moral hazard behavior do not show significant changes in the direction predicted in the research model after the introduction of the full deposit insurance system. The Wilcoxon and binomial test statistics are not significant at conventional levels. These results provide evidence that management efficiency does not change significantly after introduction of full deposit insurance.

\section{Earnings}

The simple market model suggests that the expected risk premium varies in direct proportion of its risk over the long run. The short-run relationship, however, depends on economic circumstances.

The examination of raw variable value shows that the INC ratio of the banks subject to the moral hazard behavior increased on average (median) one percentage point (one percent) after the introduction of the full deposit insurance system and $60 \%$ of all banks experienced increasing profitability (Table 3). The Wilcoxon and proportion test statistics are significant at a $10 \%$ level. However, the industry-adjusted values of the INC ratio do not show significant changes after the introduction of the full deposit insurance system. The Wilcoxon and proportion test statistics are not significant at conventional levels.

These results indicate that increases in the profitability of the banks subject to moral hazard behavior was due to economy- and industry-wide trends rather than to the introduction of the full deposit insurance system. 


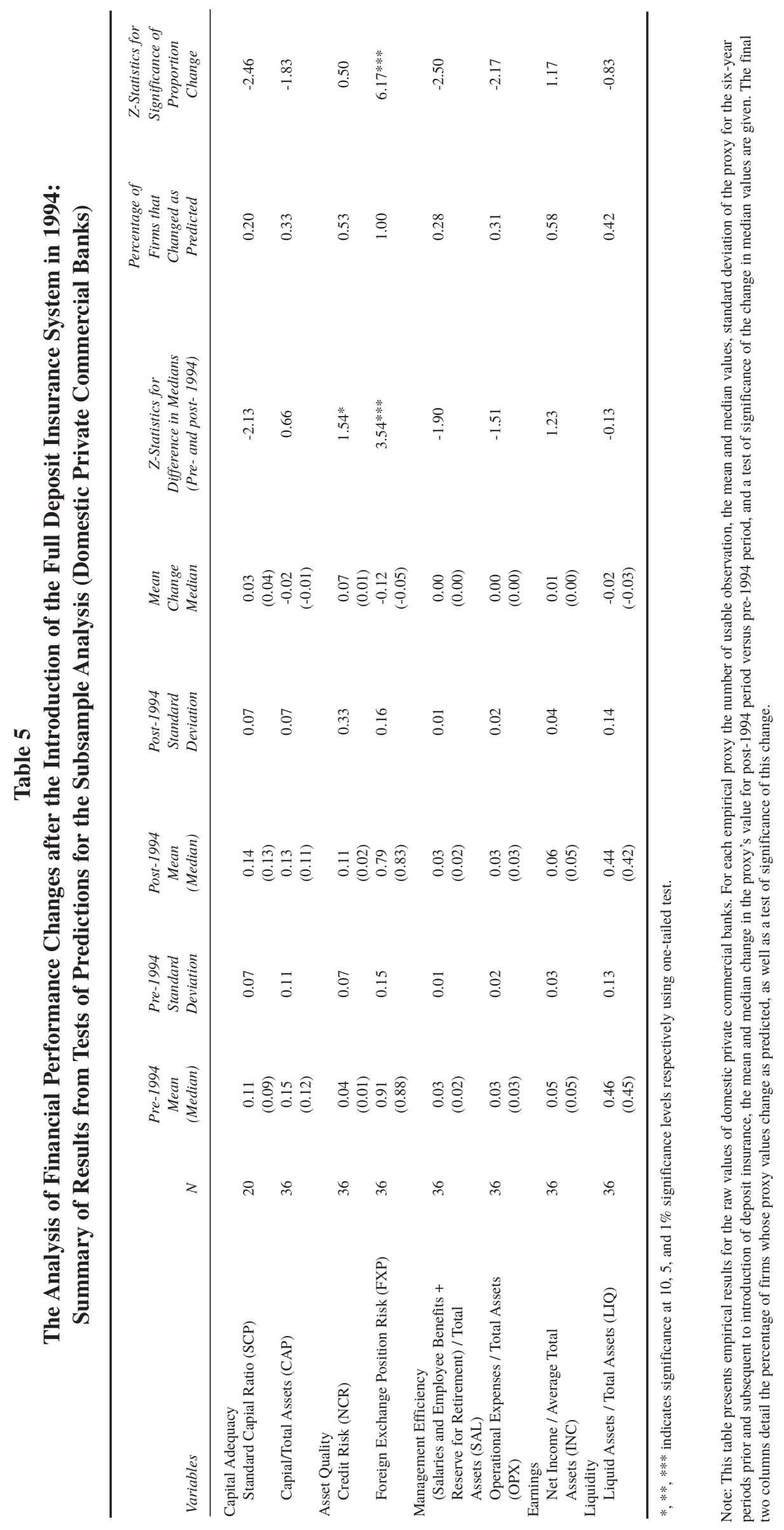




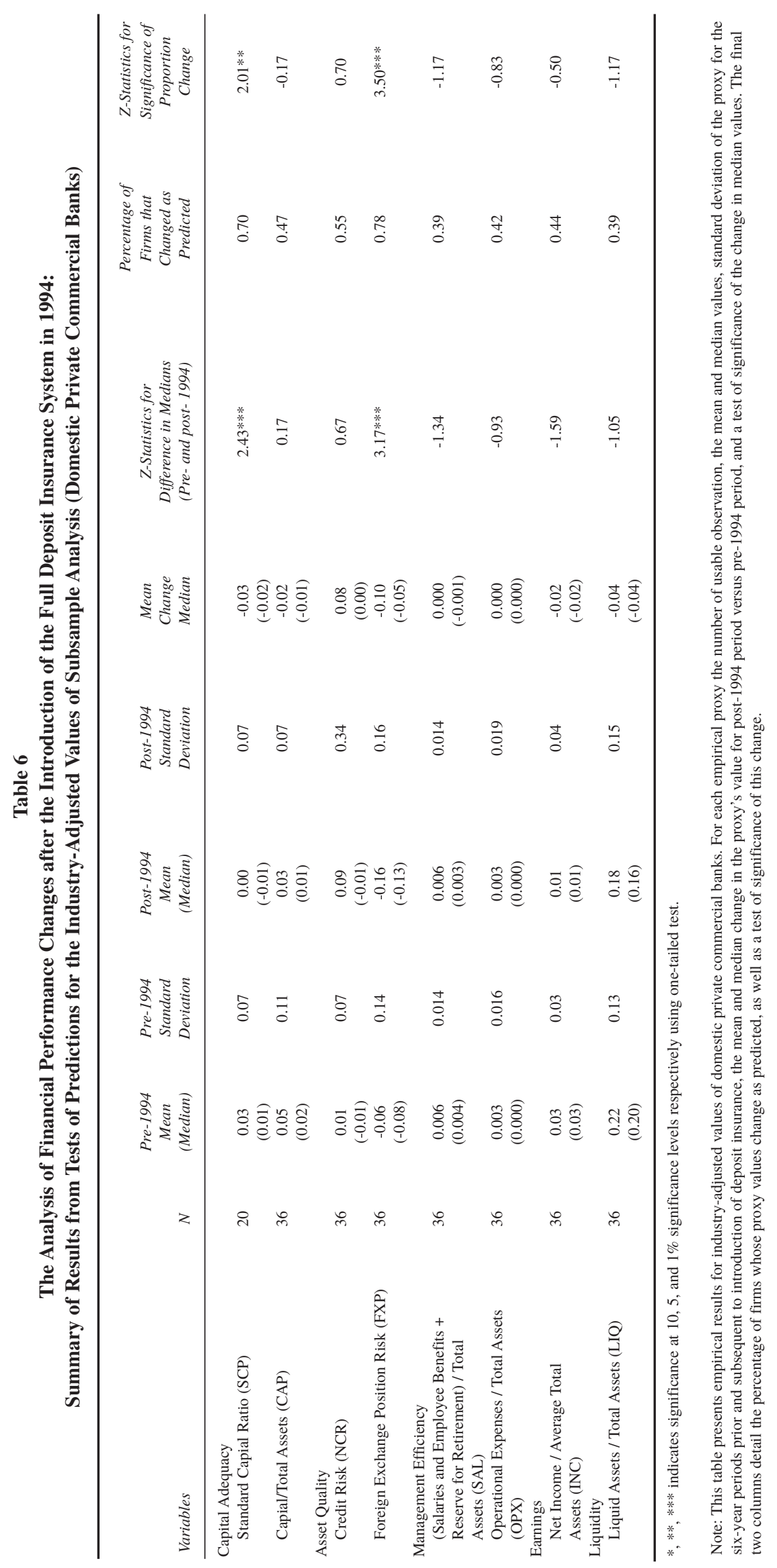




\section{Liquidity}

The research findings show that the raw and industry-adjusted values of the liquidity ratio of the banks subject to moral hazard behavior do not decrease after the introduction of the full deposit insurance system. The Wilcoxon and proportional test statistics are not significant at conventional levels. These results imply that banks subject to moral hazard behavior do not increase their vulnerability to interest rate risk after the introduction of the full deposit insurance system.

\section{SENSITIVITY ANALYSIS}

It can be argued that though deposits in foreign-owned commercial banks are covered by the full deposit insurance system, foreign-owned banks are not subject to moral hazard behavior as severely as domestic commercial banks. One of the main reasoning behind this argument is the fact that the risks of a foreign-owned commercial bank are controlled by its headquarters, since they will undertake losses in case of the bank's failure, whereas the losses of a domestic commercial bank are undertaken by the taxpayers. This case may create asymmetric risk in the banking sector and dissuade foreign-owned commercial banks from moral hazard behavior.

To test whether the raw and industry-adjusted results are sensitive to the particular research sample definition and consider the heterogeneity of the research sample, the financial performance changes of domestic private commercial banks are analyzed separately. The empirical results are reported in Tables 5 and 6.

The examination of the financial performance changes using raw variable values shows that both of the asset quality indicators experience significantly deteriorating variable values after the introduction of the full deposit insurance system. However, the significance of the changes in the credit risk variable fades when industry-adjusted variable values are taken into consideration. Similar to the findings in the previous section, there is a significant deterioration in standard capital ratio and foreign exchange position risk variables after the introduction of the full deposit insurance system. These findings support the robustness of the findings in this study.

\section{CONCLUSION AND DISCUSSION}

This paper provides empirical analysis of the effects of the deposit insurance system on the financial performance of Turkish commercial banks. For this purpose, the financial statements of all domestic and foreign-owned private commercial banks operating in the Turkish banking sector were examined and analyzed using the experimental-design approach, with industry-adjusted variable values to remove the effects of economy- and industry-wide factors on financial performance changes.

The research findings provide support the moral hazard behavior hypothesis. The findings indicate that commercial banks subject to moral hazard behavior show significant increases in foreign exchange position risk and deterioration in capital adequacy relative to their benchmark after the introduction of the full deposit insurance system. The research findings are robust in terms of the research sample definition. This excessive risk-taking is related to the moral hazard behavior by commercial banks. The research results indicate that the full deposit insurance system distorts the incentive structure of commercial banks and thus prevents the proper functioning of the market discipline mechanism and leads to excessive risk-taking. 
The research findings should be interpreted carefully. Though the study stresses that the market discipline mechanism is essential for the proper functioning banking, it does not call for the full abolition of the deposit insurance system. Since the deposit insurance system hampers the contagion effects of individual bank runs, the optimal solution for this problem should

1) not much distort the functioning of the market discipline mechanism

2) prevent the contagion effects of individual bank-runs

To compromise the first and second pillars, optimal partial deposit insurance system can be designed to prevent sudden outflows of funds without overly obstructing the proper functioning of the market discipline mechanism.

\section{NOTES}

1. Calculations are made on data from the Banks Association of Turkey.

2. This ratio is calculated by the banks according to Decree No. 23388 published by the Undersecretariat of the Treasury of Turkey in the Official Gazette on June 30,1998.

\section{REFERENCES}

Akerlof, G.A. and Romer; P. (1993). "Looting: The Economic Underworld of Bankruptcy for Profit," Brookings Papers on Economic Activity, 2: 1-73.

Allen, F. and Gale, D. (1998). “Optimal Banking Crises,” Journal of Finance, 53(4): 1245-1284.

Baer, H. and Brewer; E. (1986). "Uninsured Deposits as a Source of Market Discipline: A New Look," Quarterly Journal of Business and Economics, 24: 3-20

Barth, J., Caprio, G. and Levine, R. (2001). "Prudential Regulation and Supervision: What Works and What Doesn't." World Bank mimeo.

Beck, T. (2001). “Deposit Insurance as a Private Club: Is Germany a Model?” World Bank mimeo.

Calomiris, C. (1996). "Building an Incentive-Compatible Safety Net: Special Problems for Developing Countries." Columbia University mimeo.

Calomiris, C. and Powell, A. (2000). "Can Emerging Market Bank Regulators Establish Credible Discipline? The Case of Argentina.” World Bank mimeo.

Caprio, G. (1998). "Banking on Crises: Expensive Lessons from Recent Financial Crises," Development Research Group. The World Bank.

Caprio, G., and Klingebiel, D. (1996). "Bank Insolvencies: Cross Country Experience," Working Papers No.1620, Washington, DC: The World Bank. 
---- (1999). “Episodes of Systemic and Borderline Financial Crises.” World Bank mimeo.

Chari, V. and Jagannathan, R. (1988). "Banking Panics, Information, and Rational Expectations Equilibrium,” Journal of Finance, 43: 749-761.

Demirgüç-Kunt, A. and Detragiache, E. (2000). "Does Deposit Insurance Increase Banking System Stability?" IMF Working Paper 00/3.

Demirgüç-Kunt, A. and Huizinga, H. (2000). "Market Discipline and Financial Safety Net Design." World Bank mimeo.

Demirgüç-Kunt, A. and Kane, E. (2000). "Deposit Insurance around the Globe: Where Does It Work?” Journal of Economic Perspectives, 16(2): 175-195.

Diamond, D. and Dybvig, P. (1983). "Bank Runs, Deposit Insurance, and Liquidity," Journal of Political Economy, 91(3): 401-19.

----- (1986). “Banking Theory, Deposit Insurance, and Bank Regulation,” Journal of Business, 59(1): $55-68$.

Ellis, David and Flannery, M. (1992). "Does the Debt Market Assess Large Banks' Risk? Time Series Evidence from Money Center CDS," Journal of Monetary Economics, 30: 481-502.

Garcia, G. (1999). “Deposit Insurance: A Survey of Actual and Best Practices.” IMF Working Paper, No. 99/54.

Hall, M.J.B. (ed.) (2001). "The Regulation and Supervision of Banks: The Case For and Against Banking Regulation," Vol. 1, The International Library of Critical Writings in Economics 133, Edward Elgar Publishing, UK.

Hannan T. and Hanweck, G. (1988). "Bank Insolvency Risk and the Market for Large Certificates of Deposit," Journal of Money, Credit, and Banking, 20: 203-211

Honohan, P. and Klingebiel, D. (2000). “Controlling Fiscal Costs of Banking Crises.” World Bank mimeo.

Kane, E. (1995). "Three Paradigms for the Role of Capitalization Requirements in Insured Financial Institutions," Journal of Banking and Finance, 19: 431-459.

----- (2000). “Designing Financial Safety Nets to Fit Country Circumstances.” World Bank mimeo.

Kane, E. and Demirgüç-Kunt, A. (2001). "Deposit Insurance around the Globe: Where Does It Work?" NBER Working Paper, Nr. 8493.

Kaplan, I. (1998). “The Put Option Approach to Banking Crises in Emerging Markets: Valuing Implicit Deposit Insurance in Thailand," University of Washington mimeo. 
Kaufman, G.G. (ed.) (1995). Banking, Financial Markets, and Systemic Risk. Vol. 7. Research in Financial Services: Private and Public Policy. Greenwich, CT, JAI Press.

Keeley, C. (1990). “Deposit Insurance, Risk and Market Power in Banking," American Economic Review, 80(5): 1183-99.

McKinnon, R.I. and Pill, H. (1999). "Exchange Rate Regimes for Emerging Markets: Moral Hazard and International Overborrowing," Oxford Review of Economic Policy, 15: 19-38.

Park S. and Persistani, S. (1998). "Market Discipline by Thrift Depositors," Journal of Money, Credit, and Banking, 30: 347-364.

Park, S. (1995). "Market Discipline by Depositors: Evidence from Reduced-form Equations," Quarterly Review of Economics and Finance, 35: 497-514.

Paroush, J. (1988). "The Domino Effect and the Supervision of the Banking System," Journal of Finance, 38(5): 1207-18.

Pettway, R.H. (1980). "Potential Insolvency, Market Efficiency, and Bank Regulation of Large Commercial Banks," Journal of Financial and Quantitative Analysis, 40: 219-236.

Scott, K. and Weingast, B. (1994). "Banking Reform: Economic Propellants, Political Impediments," in G.G. Kaufman (ed.), Reforming Financial Institutions and Markets in the United States: 19-36.

World Bank (2000). Turkey: Country Economic Memorandum, Structural Reforms for Sustainable Growth, Report No. 20657-TU, Vol. 1. 